\title{
Intervention Model Using a Game to Improve Knowledge and Attitudes of Mothers in Reproductive Age of Reproductive Health in Pernantin Village of Juhar, Karo District, Indonesia
}

\author{
Sri Paulina Riah Ukurta , Agustin Kusumayati², and Syarifah² \\ ${ }^{1}$ Universitas Indonesia, Depok, Indonesia \\ ${ }^{2}$ Universitas Sumatera Utara, Indonesia
}

\section{Abstract}

The high rate of maternal mortality is one indicator of national welfare in Indonesia. One contributing factor toward this problem is mothers' lack of knowledge of reproductive health resulting from their lack of education. The use of a snakes and

Corresponding Author: Sri Paulina Riah Ukurta sripaulinakaban@gmail.com Agustin Kusumayati agustin.kusumayati@ui.ac.id

Received: 21 January 2018 Accepted: 8 April 2018 Published: 17 May 2018

Publishing services provided by Knowledge

(a) Sri Paulina Riah Ukurta et al. This article is distributed under the terms of the Commons Attribution License, which permits unrestricted use and redistribution provided that the original author and source are credited.

Selection and Peer-review under the responsibility of the 2nd International Meeting of Public Health 2016 Conference Committee. ladders game could be one way of improving mothers' knowledge. This game was previously implemented along with the distribution of an informational leaflet in the fishing community of Bagan Deli Village. The aim of this study was to examine the effect of this game intervention on the knowledge and attitudes of respondents in Pernantin village. This quasi-experimental study included a pre-test, an intervention, and a post-test. Respondents, consisting of 48 mothers of reproductive age (20-45 years old), were divided into two groups: the control group and the intervention group. According to a t-test, the intervention group, consisting of 24 respondents, showed an improvement in their knowledge $(p<0.05)$, while no difference was found in their attitudes $(p>0.05)$. This result proved that the snakes and ladders game and leaflets were effective as an intervention to improve the health knowledge of mothers in reproductive age. Based on these results, it is important to provide information on reproductive health to mothers of reproductive age in such villages or elsewhere. It is also important to develop other ways of creatively imparting knowledge that are easily understood by mothers.

Keywords: knowledge and attitude, mothers of reproductive age, intervention

\section{INTRODUCTION}

A mother can optimally perform her roles as caregiver, worker, educator of her chilS OPEN ACCESS dren, housekeeper, companion for her husband and member of the community if 
she is physically, mentally, and socially healthy. The well-being of the mothers is highly dependent on the quality of human resources and services provided, wherein intervention efforts to guarantee the reproductive health and safety of mothers should occur early as possible to avoid negative outcomes (Maas 1997). According to UNDP, the maternal mortality rate (MMR) is one of the standards of prosperity for a nation. Based on the annual report of the United Nation Population Fund Agency (UNFPA), the MMR in Indonesia was 450 per 100,000 live births in 1999 [2]. Meanwhile, according to SKRT (Household Health Survey) in 1992, the MMR in Indonesia was 420 per 100,000 live births. In 1994, the number dropped to 390 (Warta Gender 1999) and, in 1997, declined to 337 per 100,000 live births [1]. Maternal mortality varies widely in different regions. Bali was estimated to have 118-120 maternal deaths per 100,000 live births in 1985-1986. In Java, during 1989, the MMR reportedly varied from 490 in West Java to 340 in Central Java; the lowest rate (130) was found in Yogyakarta. Meanwhile, in East Nusa Tenggara, the MMR was reported to be very high at 1,340 deaths per 100,000 births [3]. The MMR in North Sumatra, as reported by BKKBN (National Family Planning Coordinating Board of North Sumatra), also differed in several regions: 1,200 in Deli Serdang, 900 in Tapanuli Tengah, 800 in Dairi, 400 in North Tapanuli, and 100 in Tanah Karo [5]. The above mentioned figures are very high compared to the countries surrounding Indonesia. In 1999, the MMR of Malaysia was one-tenth that of Indonesia at 39, while Vietnam was at 215, Singapore at 19, and Hong Kong at 9. Japan experienced an MMR of only 1 per 100,000 live births [2]. Clinically, the high maternal mortality rate is caused by the three common factors: hemorrhage (40-60\%), preeclampsia/eclampsia (20-30\%) and infection (20-30\%). These factors can be compounded by obstructed labor and other complications that can occur at any time during a mother's pregnancy. As seen in the data, bleeding is the most common cause of maternal death. Even in Bali, the research reported that $67 \%$ of maternal deaths were associated with bleeding. These incidents, coupled with delays in medical treatment, delayed check-ups at appropriate medical facilities, late arrival at health facilities, young age of marriage, old age at pregnancy, frequent pregnancy, or too many childbirths, can cause complications [9]. In addition, other factors likely contribute toward women's well-being and reproductive health:

1. Low levels of education lead to a lack of knowledge and awareness of reproductive health. According to Hadad (1997), who was cited in Syarifah et al. (1999), reproductive health is not attained by many mothers and families because of several factors: The lack of sexual education resulting from low levels of education, 
and the presence of cultural taboos against openly discussing matters relating to reproductive health and sexuality.

2. Incomplete information on reproductive health, or the addition of services without appropriate and sufficient health facilities and services, also represents a barrier.

3. Social practices are discriminatory, as women receive less comprehensive education in comparison to men, receive lower wages in comparison to men for the same work, and are subjected to a patriarchal culture that makes women subordinate; these factors can also reflect in the health of women.

4. Degrading attitudes toward women are detrimental to their sexual and reproductive lives; as such attitudes can prevent women from making the correct decisions for themselves.

High MMR is closely associated with the lack of knowledge of a community, especially of mothers in regard to reproductive health, as well as lack of health checks during pregnancy. Education and knowledge of reproductive health are known to reduce the MMR. Much can be done to improve knowledge on and attitudes toward reproductive health. One intervention is a game of snakes and ladders to improve reproductive health knowledge. Results of a study conducted by Syarifah et al. (1999), who developed a model of snakes and ladders to improve reproductive health knowledge in fishing communities in Bagan Deli Medan, resulted in increased knowledge of reproductive health in women following the intervention. A large increase in the knowledge and improvement in the attitudes of respondents after the invention was notable in comparison to before the intervention. Therefore, this study aimed to examine the effect of a similar intervention to improve women's knowledge of and attitudes toward reproductive health through evaluating the effect of an educational snakes and ladders game among women of the Pernantin farming community.

\section{METHODS}

This study was a quasi-experimental study including a pre-test, an intervention, and a post-test. The respondents were 48 mothers in reproductive age (20-45 years old) in Pernantin Village of Juhar, Karo District, who were divided into two groups: the control group and the intervention group. The researcher collected the data by asking the questions listed on the questionnaire. The obtained data were analyzed using a t-test. The game (intervention): the researcher played with mothers of intervention group. 
Two or more players played on a game board having numbered, gridded squares. A number of "ladders" and "snakes" are pictured on the board, each connecting two specific board squares. Some squares filled with reproductive health message. The object of the game is to navigate one's game piece, according to die rolls, from the start (bottom square) to the finish (top square), helped or hindered by ladders and snakes respectively. While the players played the game, the researcher explains each picture squares.

\section{RESULTS}

From the table above, most of the respondents in the control group were aged either 30-34 or 35-39 years (each group represented $25 \%$ of respondents). Most respondents in both groups had a high school education and were married in the age range of 2024 years. The majority of respondents also had their first children at the age of 20-24 years and had 1-2 children. Both groups had husbands who were aged between 3034 years. Eleven respondents reported using contraception (45.8\%), while 13 did not $(54.2 \%)$, although these figures reflected those women who stopped using contraception because of a negative reaction as well as others women who were already pregnant and had stopped using contraception.

Most respondents had never heard or learned about reproductive health, or 15 respondents (62.5\%) in the control group and 22 respondents ( $91.7 \%)$ in the intervention group. In general, they received information about reproductive health through the midwives, including 6 respondents $(25 \%)$ in the control group and 3 respondents $(12.5 \%)$ in the intervention group.

The level of knowledge of mothers per group was divided into three categories (good, moderate, and poor) based on their performance on the pre-test and the posttest; the changes in the level of knowledge about reproductive health can be observed in Table 2.

Table 2 shows that changes in the level of knowledge were significant for the intervention group. Changes occurred across most categories of knowledge in comparing the pre-test and the post-test results. In the intervention group, 15 respondents $(62.5 \%)$ with poor knowledge on the pre-test shifted to moderate or good knowledge on the post test following the intervention. The number of respondents with a moderate level of knowledge amounted to $9(37.5 \%)$ prior to the intervention but increased considerably after the intervention. Also, following the intervention, a total of 10 people ( $41.7 \%)$ demonstrated a good level of knowledge. 
TABLE 1: Respondent Characteristics.

\begin{tabular}{|c|c|c|c|c|}
\hline \multirow[t]{2}{*}{ Variable } & \multicolumn{2}{|c|}{ Control Group } & \multicolumn{2}{|c|}{ Intervention Group } \\
\hline & $\Pi$ & $\%$ & n & $\%$ \\
\hline \multicolumn{5}{|c|}{ Age group (уear) } \\
\hline $20-24$ & 5 & 20.8 & 8 & 33.3 \\
\hline $25-29$ & 5 & 20.8 & 4 & 16.7 \\
\hline $30-34$ & 6 & 25.0 & 5 & 20.8 \\
\hline $35-39$ & 6 & 25.0 & 1 & 4.2 \\
\hline $40-45$ & 2 & 8.4 & 6 & 25.0 \\
\hline \multicolumn{5}{|c|}{ Education } \\
\hline SD & 2 & 8.3 & 5 & 20.8 \\
\hline SLTP & 6 & 25 & 4 & 16.7 \\
\hline SMU & 16 & 66.7 & 14 & 58.3 \\
\hline $\mathrm{D}_{3} / \mathrm{PT}$ & 0 & 0 & 1 & 4.2 \\
\hline \multicolumn{5}{|c|}{ Marriage age (уеar) } \\
\hline $15^{-19}$ & 7 & 29.2 & 9 & 37.5 \\
\hline $20-24$ & 14 & 58.3 & 13 & 54.2 \\
\hline $25-29$ & 3 & 12.5 & 2 & 8.3 \\
\hline \multicolumn{5}{|c|}{ Age of having first child (year) } \\
\hline $15^{-19}$ & 4 & 16.7 & 5 & 20.8 \\
\hline $20-24$ & 14 & 58.3 & 17 & 71.0 \\
\hline $25-29$ & 6 & 25.0 & 2 & 8.3 \\
\hline \multicolumn{5}{|c|}{ Number of children } \\
\hline$<2$ & 16 & 66.7 & 14 & 58.3 \\
\hline$>2$ & 8 & 33.3 & 10 & 41.7 \\
\hline \multicolumn{5}{|c|}{ Husband age (уear) } \\
\hline $20-24$ & 1 & 4.2 & 4 & 16.7 \\
\hline $25-29$ & 6 & 25.0 & 2 & 8.3 \\
\hline $30-34$ & 6 & 25.0 & 6 & 25.0 \\
\hline $35-39$ & 5 & 20.8 & 2 & 8.3 \\
\hline $40-45$ & 3 & 12.5 & 5 & 20.8 \\
\hline \multicolumn{5}{|c|}{ Use of contraception } \\
\hline Yes & 11 & 45.8 & 11 & 45.8 \\
\hline No & 13 & 54.2 & 13 & 54.2 \\
\hline
\end{tabular}

Data analysis according to a t-test at a $95 \%$ confidence level $(p=0.05)$ showed a significant difference between the level of knowledge before and after the intervention. The results of this analysis can be seen in Table 3 .

At a $95 \%$ probability ( $p$-value<0.05), the table shows a difference between the respondents' knowledge before the intervention and after the intervention. Knowledge of respondents increased after the intervention based on the snakes and ladders 
TABLE 2: Knowledge level of reproductive health.

\begin{tabular}{|l|c|c|c|c|c|c|c|c|c|}
\hline \multirow{2}{*}{ Knowledge Level } & \multicolumn{4}{|c|}{ Control Group } & \multicolumn{4}{c|}{ Intervention Group } \\
\hline & \multicolumn{2}{|c|}{ Pre test } & \multicolumn{2}{c|}{ Post test } & \multicolumn{2}{c|}{ Pre test } & \multicolumn{2}{c|}{ Post test } \\
\hline & n & $\%$ & $n$ & $\%$ & $n$ & $\%$ & $n$ & $\%$ \\
\hline Good & 1 & 4.2 & 1 & 4.2 & 0 & 0 & 10 & 41.7 \\
\hline Moderate & 13 & 54.2 & 13 & 54.2 & 9 & 37.5 & 14 & 58.3 \\
\hline Poor & 10 & 41.7 & 10 & 41.7 & 15 & 62.5 & 0 & 0 \\
\hline Total & 24 & 100 & 24 & 100 & 24 & 100 & 24 & 100.0 \\
\hline
\end{tabular}

TABLE 3: T-test result of the level of knowledge before and after the intervention.

\begin{tabular}{|c|c|c|c|c|}
\hline Frequency & Mean & t-test & $d f$ & P value \\
\hline 24 & -25.58 & -11.517 & 23 & 0.000 \\
\hline
\end{tabular}

game and leaflets. In other words, the intervention model of snakes and ladders and leaflets was proven effective in significantly improving mothers' knowledge.

However, based on the data analysis using the statistical t-test at a 95\% confidence level $(p=0.05)$, no significant effects were observed in respondents' attitudes before and after the intervention. The results of this analysis can be seen in Table 4 at following.

TABLE 4: T-test result of respondents' attitudes before and after the intervention.

Frequency

24

Mean
-0.42

t-test
-0.312

$d f$
23

\section{p value}

0.758

The table above shows a probability of $p=0.758$. Therefore, this confirms the lack of significant differences between the attitudes of the respondents before and after the intervention. In other words, the intervention of the game and leaflets did not significantly improve attitudes toward reproductive health.

\section{DISCUSSION}

Based on the present study on the knowledge and attitudes of women with respect to reproductive health, respondents' knowledge was considerably low. Many respondents had never heard about reproductive health. This was reflected in their lack of awareness of reproductive health issues. The results indicated that respondents received most information on the topic from a midwife or a nurse, reminding us of the importance of health workers and their role in distributing and explaining reproductive health. Respondents' knowledge of family planning was moderate; in general, they recognized that family planning or visiting Planned Parenthood is one method 
to adjust the spacing of births or to limit the number of children. However, they did not have much knowledge about the type of contraception that they should use or that suited their needs. Their knowledge of contraception types was limited to pills and contraceptive coils, as they generally use only one or the other. The data revealed that respondents knew when to consult to their doctors and midwives during their pregnancies. Their comprehension of food intake during pregnancy was sufficient but contrasted with their actual diet. Many respondents did not eat varied foods available in the village. According to Kholil et al. (1999), this may lead to a lack of maternal nutrition during pregnancy, which can cause malnutrition in the unborn child. If a pregnant mother suffers from certain diseases, poor nutrition would worsen the situation and possibly result in infant death. Nutritional status is also an important factor for maintaining the health and stamina of mothers. Food intake of mothers before and during the pregnancy and during breastfeeding was inadequate in terms of calories and micronutrients. Iron deficiency, or anemia, is experienced by the majority of pregnant women in Indonesia and can worsen the physical state of a mother who is already weak and also increase the risk of death as a result of bleeding.

The game implemented in this study was previously evaluated in the fishing community of Bagan Deli Village. The statistical t-test analysis permitted differences in the knowledge level and attitudes of mothers in reproductive age with respect to reproductive health to be determined. Specifically, knowledge and attitudes were examined before and after an intervention model that involved a snakes and ladders games and informational leaflets, which were given to the intervention group ( $p<0.05)$. Improvements were shown to occur as a result of this intervention. These results are consistent with the theory expressed by WHO (1992) that knowledge can be established through information provided by others such as teachers, friends, and books, as well as through communication media such as radio, television, posters, magazines, and newspapers. According Fofana (1997), the success of these efforts is also evident from research in several other countries such as Nigeria, Ghana, and West Africa where awareness of health care issues increased through weekly meetings with community leaders, film shows, posters, and banners; in this context, the ease of attainment of health care can reduce mortality and health risks [6]. Furthermore, respondents should not passively receive information but should also actively participate in discussions about the information they receive. Thus, knowledge of health can form the basis of their health-related behaviors, wherein good behaviors will serve as a reference to others. Therefore, discussions and participatory methods are good ways to provide information and health messages. Based on the results of a t-test at a $95 \%$ confidence level, no 
significant effect of the intervention on the attitudes of respondents was found in the intervention group ( $p>0.05$ ). In this case, the research instruments may have been less able to measure changes. The questionnaire did not specifically measure changes as a result of the intervention but did demonstrate that respondents received a higher score after the intervention. However, knowledge did increase pre and post intervention, even though this did not affect attitudes, which could ultimately lead to changes in actions. This is also understandable considering that changes in attitudes and actions can take a long time to achieve; this new intervention demonstrates that a high degree of knowledge does not necessarily translate into a change in attitudes or actions. This is consistent with the theory expressed by Notoatmodjo (1993) that attitude changes is a reaction or response that cannot occur in someone who is closed off to a stimulus or object. Therefore, the manifestation of an attitude can be interpreted in terms of behaviors or willingness to change behaviors.

\section{CONCLUSIONS}

This research study examined the effect of a snakes and ladders game on knowledge about reproductive health and attitudes toward reproductive health in mothers of reproductive age. The findings of this study confirm that the game of snakes and ladders and the use of leaflets were effective as interventions for improving knowledge of reproductive health. This activity can also be applied in other villages under the assumption that most villagers have not heard of reproductive health or received education on this topic. For further study, I recommend that health workers provide sufficient knowledge about reproductive health to mothers of reproductive age in ways that are more creative and easily understood by them.

\section{ACKNOWLEDGEMENTS}

The author would like to thank to the lecturers Dra. Syarifah, M.S., and Drs. Eddy Syarial, M.S. for their informative encouragement. This study was presented to the International Meeting of Public Health as a full paper.

\section{References}

[1] Depkes, R. I. Sumatera Utara. Profil Kesehaton Propinsi Sumatera Utara. 
[2] Keluarga Online. (1999). Kampanye Suami Siaga \& Gerakan Sayang Ibu. Retrieved June 25, 2002 from www.keluarga.org.

[3] Kholil A., M. B. Iskandar, \& R. Sciortino. (1999). Penyelamat Kehidupan: Gerakan Sayang Ibu di Indonesia. Galang Communication dan Kantor Menteri Negara Peranan Wanito RI (1 ${ }^{\text {st }}$ ed.). Jakarta: Ford Foundation.

[4] Maas, L. T. (2004). Kesehatan dan Reproduksi. Karya Ilmiah. Fakultas Kesehatan Masyarakat Universitas Sumatera Utara.

[5] PPKRM-IWB USU. (1999). Buletin Pusat Pengembangan Kesehatan Reproduksi Manusia Indonesia Wilayah Barat Universitas Sumatera Utara, First Year, No.1

[6] Sarumpaet, S. (2001). Komplikasi Persalinan dan Analisis Upaya Penanganannya di Propinsi Sumatera Utara. Pengukuhan Jabatan Guru Besar Tetap dalam Ilmu Kesehatan Masyarakat pada Fakultas Kesehatan Masyarakat di USU. Medan

[7] Syarifah, Z. F., \& R. F. Dalimunthe. (1999). Pengembangan Model Intervensi Untuk Meningkatkan Kesehatan Reproduksi Melalui Peningkatan Potensi Keluarga Pada Masyarakat Nelayan Di Kelurahan Bagan Deli Kotamadya Medan. Kerjasama FKM USU dengan Bapelkes Depkes RI.

[8] WHO, (1992). Pendidikan Kesehaton. Pedoman Pelayanan Kesehatan Dasar

[9] WHO-DepkesRI-FKM UI. (1999). Modul Safe Motherhood. 